\title{
Música popular urbana e fronteiras em Mato Grosso do Sul no livro de Álvaro Neder
}

\author{
Urban Popular Music and Borders in Mato Grosso do Sul \\ in Álvaro Neder's Book
}

\section{Evandro Higa}

Universidade Federal de Mato Grosso do Sul, Campo Grande, Mato Grosso do Sul, Brasil. evandrohiga304@gmail.com

Resumo: Resenha do livro NEDER, Álvaro. Enquanto este novo trem atravessa o litoral central: música popular urbana, latino-americanismo e conflitos sobre modernização em Mato Grosso do Sul. Rio de Janeiro: Mauad, 2014. 340 p. R\$60,00.

Palavras-chave: música popular; Mato Grosso do Sul; América Latina; fronteiras.

Abstract: Book review of Álvaro Neder's Enquanto este novo trem atravessa o litoral central: música popular urbana, latino-americanismo e conflitos sobre modernização em Mato Grosso do Sul. Rio de Janeiro: Mauad, 2014. 340 p. R\$60,00.

Keywords: popular music; Mato Grosso do Sul; Latin America; borders.

Data de recebimento: 03/11/2015.

Data de aprovação final: 18/03/2016.

A construção de gêneros musicais na música popular não pode ser analisada sem levar em conta os processos históricos, sociais, econômicos e culturais que compõem a complexa teia de significações que estão associadas aos discursos identitários. A análise das estruturas rítmicas, melódicas, harmônicas e formais, conquanto necessária, por si só não é suficiente para compreender as motivações e consequências das categorizações genéricas e sua força simbólica. 
A partir de um olhar transdisciplinar, Álvaro Neder realiza um recorte da produção musical de Mato Grosso do Sul para analisar o que denomina de Música do Litoral Central (MLC): conjunto da produção de compositores urbanos daquele Estado construída a partir da década de 1960 e que atingiu seu clímax na década de 1970/80.

Tratando a canção popular como instância discursiva e tendo sempre em vista os conflitos e negociações entre as forças produtivas do campo e da cidade, são analisadas as complexas relações entre o local, o nacional, o sul-americano e o global que atravessam a obra de músicos como Geraldo Espíndola, Almir Sater, Paulo Simões, Geraldo Roca, Lenilde Ramos, Grupo ACABA e muitos outros.

Nos discursos musicais desses artistas, o autor detecta o que denomina de "poética do deslocamento" como uma "contínua migração entre diferentes posições subjetivas" (p.63) e um certo "desfronteiramento" que aponta para uma intertextualidade metaforizada nas imagens recorrentes do rio Paraguai (e do Pantanal) e do trem não apenas como rota de fuga mas também como "procura do movimento e atração pela indeterminação" (p.63).

Segundo Neder, o termo "Música do Litoral Central" - proposto pelo compositor Geraldo Roca - remete a um tipo de canção urbana surgido em Campo Grande na década de 1960 e que, apesar de inicialmente não apresentar uma unidade estética, estilística e ideológica, e nem ser considerada "regional", serviu ao projeto de construção identitária de Mato Grosso do Sul antes, durante e depois de realizada a divisão do antigo Mato Grosso no final dos anos 1970, já que "os discursos dominantes viriam a favorecer, a partir da divisão, a entronização da MLC como identidade representativa de Mato Grosso do Sul" (p.119).

Se debatendo nas categorias dicotômicas do arcaico/moderno e campo/cidade, e apesar da inspiração musical caipira e paraguaia, hibridizada com a MPB, o folk e o rock americanos, a MLC e seus músicos foram detentores de grande prestígio na cidade de 
HIGA, Evandro. (2016) Música popular urbana e fronteiras em Mato Grosso do Sul no livro de Álvaro Neder. Per Musi. Ed. por Fausto Borém, Eduardo Rosse e Débora Borburema. Belo Horizonte: UFMG, n.34, p.206-210.

Campo Grande e muito pouco sucesso econômico e popularidade no restante do Estado, haja vista seu perfil urbano que não se confundiu com o universo cultural dos trabalhadores rurais ou das camadas urbanas que mantinham fortes identificações com a ruralidade.

Contraditória, apesar de cooptada pelas elites locais após a década de 1970 e de desfrutar do prestígio de seu capital simbólico, a MLC "não privilegiava o polo da tradição - relacionada, como regionalismo, aos interesses dominantes -, que era aqui alterada, transformada, tornando-se, não mais familiar ou nostálgica, mas estranha" (p.146), e, de um modo geral, "as canções iam a contrapelo, tanto do desenvolvimentismo exclusionário, quanto dos discursos ufanistas e conciliadores do regionalismo, ao propor um diálogo entre o rural, a América Latina e o mundial" (p.133).

Esse prestígio local, que atingiu o ápice na década de 1980 com a difusão dos apelos ecológicos em defesa do Pantanal, levou a MLC a uma certa "defesa essencialista de raízes regionais", associando-se a um "ideário solene, pedagogizante e limitador", passando às novas gerações uma "imagem retrógrada, do mato, da natureza, do passado" (p.162).

Neder conclui sua narrativa observando que a proposta da MLC "baseia-se na ideia de fragmentação, não de integração", e que sua opção por um discurso que excluiu "o universo cultural das populações periféricas da cidade de Campo Grande e rurais do restante de Mato Grosso do Sul, em última análise, não chegou a promover efeitos sobre elas" (p.325).

No primeiro capítulo o autor faz uma análise do contexto histórico-social em que está inserido o atual Mato Grosso do Sul, partindo da guarânia "Sonhos guaranis" de Paulo Simões e Almir Sater que aborda o triste episódio da Guerra da Tríplice Aliança no século XIX e aponta para uma possível integração latino-americana nesta "fronteira onde o Brasil foi Paraguai". 
HIGA, Evandro. (2016) Música popular urbana e fronteiras em Mato Grosso do Sul no livro de Álvaro Neder. Per Musi. Ed. por Fausto Borém, Eduardo Rosse e Débora Borburema. Belo Horizonte: UFMG, n.34, p.206-210.

No segundo capítulo, o reggae "Vida cigana" de Geraldo Espíndola fornece o mote para a demonstração da tese da poética do deslocamento e as práticas culturais contraditórias de Campo Grande exemplificadas no clube social da elite local (Rádio Clube), no qual, desde os anos 1920, os modelos desenvolvimentistas e modernizantes se debatiam dialeticamente com a cultura paraguaia e fronteiriça.

É porém no terceiro capítulo que Neder mergulha de cabeça na tese de que a divisão Mato Grosso/Mato Grosso do Sul foi decisiva para a entronização da MLC e seus agentes como bandeira identitária apoiada em idílicas imagens ecológicas de um pantanal idealizado em uma complexa teia discursiva. A busca de referencias culturais para legitimar os diversos projetos de poder das elites locais tem como trilha musical a canção "Cunhataiporã”, de Geraldo Espíndola, que pergunta "onde você quer ir, meu bem?" ao mesmo tempo em que aponta os destinos e as referencias possíveis (Ponta Porã, Corumbá, trem, barco, Rio Paraguai) e conclui nostalgicamente "cantando as canções que não se ouvem mais".

É aqui que o autor analisa os diversos festivais de música, projetos culturais e as faixas do icônico LP "Prata da casa" do início da década de 1980 e considerado uma espécie de "manifesto" informal da MLC, sem poupar do rigor da crítica músicos como Tetê Espíndola, Geraldo Espíndola e o Grupo Acaba, bem como o escritor José Octávio Guizzo, autor das primeiras obras que abordaram a produção musical do Estado, por seu nacionalismo andradiano e preocupação em negar as influências paraguaias ao desconsiderar os conflitos econômicos e políticos da região.

Finalmente, no quarto capítulo, o autor esclarece de onde fala e suas conexões com a cultura local, já que é campo-grandense, neto de paraguaia, primo do compositor Paulo Simões, filho de Margarida Neder (que manteve durante anos um espaço cultural em Campo Grande inspirado na cultura latino-americana, a Peña Eme-Ene), tendo sido músico amador iniciante nos anos 1970 e trabalhado na Rádio Educativa Estadual na década de 1990. 
Um dos grandes méritos da obra é, através de profundas reflexões e apoiado em sólidas referências teóricas, trazer para o foco a produção musical de um Brasil fronteiriço e com muitas conexões latino-americanas. Como afirma na introdução: "pouco se sabe, na literatura acadêmica, sobre esse Brasil interiorano e fronteiriço à América Platina sendo pertinente propor uma pouco frequente reflexão sobre as relações de uma parte fronteiriça do Brasil com esses países tão próximos, histórica e geograficamente, e, no entanto, tão distantes de nossos corações e mentes" (p.20).

\section{Referência}

1. NEDER, A. (2014) Enquanto este novo trem atravessa o litoral central: música popular urbana, latino-americanismo e conflitos sobre modernização em Mato Grosso do Sul. Rio de Janeiro: Mauad.

Nota sobre o autor

Evandro Higa é professor no curso de música da Universidade Federal de Mato Grosso do Sul, mestre em musicologia pela ECA-USP e doutor em música pela UNESP Instituto de Artes. É autor do livro "Polca paraguaia, guarânia e chamamé - estudos sobre três gêneros musicais em Campo Grande, MS” (Editora da UFMS), publicou artigo no livro "Los linguajes del território platino" (Editora da Universidade de Buenos Aires) e é co-autor de verbetes na Bloomsbury Encyclopedia of Popular Music of the World, volume IX, Genres: Caribbean and Latin America. 